\title{
A Fuzzy Decision Support System for Management of Breast Cancer
}

\author{
Ahmed Abou Elfetouh Saleh \\ Dept. of Information Systems, \\ Faculty of computer and \\ information system \\ Mansoura University \\ Mansoura, Egypt \\ elfetouh@gmail.com
}

\author{
Sherif Ebrahim Barakat \\ Dept. of Information Systems, \\ Faculty of computer and \\ information system \\ Mansoura University \\ Mansoura, Egypt \\ sherifiib@yahoo.com
}

\author{
Ahmed Awad Ebrahim Awad \\ Dept. of Information Systems, \\ Faculty of computer and \\ information system \\ Mansoura University \\ Mansoura, Egypt \\ ahmedaweb@yahoo.com
}

\begin{abstract}
In the molecular era the management of cancer is no more a plan based on simple guidelines. Clinical findings, tumor characteristics, and molecular markers are integrated to identify different risk categories, based on which treatment is planned for each individual case.

This paper aims at developing a fuzzy decision support system (DSS) to guide the doctors for the risk stratification of breast cancer, which is expected to have a great impact on treatment decision and to minimize individual variations in selecting the optimal treatment for a particular case.

The developed system was based on clinical practice of Oncology Center Mansoura University (OCMU)

This system has six input variables (Her2, hormone receptors, age, tumor grade, tumor size, and lymph node) and one output variable (risk status). The output variable is a value from 1 to 4; representing low risk status, intermediate risk status and high risk status. This system uses Mamdani inference method and simulation applied in MATLAB R2009b fuzzy logic toolbox.
\end{abstract}

Keywords: Decision Support System; Breast Cancer; Fuzzy Logic; Mamdani Inference;

\section{INTRODUCTION}

In recent years, the methods of Artificial Intelligence have largely been used in the different areas including the medical applications. In the medical field, many decision support systems (DSSs) were designed, as Aaphelp, Internist I, Mycin, Emycin, Casnet/Glaucoma, Pip, Dxplain, Quick Medical Reference, Isabel, Refiner Series System and PMA $[1,2,3,4,5,6,7]$ which assist physicians in their decisions for diagnosis and treatment of different diseases.

In cancer management many DSSs have been developed as ONCOCIN [1], OASIS, Lisa [8, 9].

The diagnosis of disease involves several levels of uncertainty and imprecision [10]. According to Aristotelian logic, for a given proposition or state we only have two logical values: true-false, black-white, 1-0. In real life, things are not either black or white, but most of the times are grey. Thus, in many practical situations, it is convenient to consider intermediate logical values. Uncertainty is now considered essential to science and fuzzy logic is a way to model and deal with it using natural language. We can say that fuzzy logic is a qualitative computational approach. Fuzzy logic is a method to render precise what is imprecise in the world of medicine.

Many medical applications use fuzzy logic as CADIAG [11], MILORD [11], DOCTORMOON [12], TxDENT [13], MedFrame/CADIAG-IV [14], FuzzyTempToxopert [14] and MDSS [15].

In the field of breast cancer, DSS is very important, as breast cancer is the most common cause of cancer death among women worldwide, in Egypt, breast cancer is the most common cancer among women; representing $18.9 \%$ of total cancer cases [16]. The National Cancer Institute (NCI) reported a series of 10556 patients with breast cancer during the year 2001.

The diagnoses have a lot of confounding alternatives, some of them are uncertain as Her2-neu positivity, hormone receptor status and age. Therefore the treatment planning is based on the interaction of a lot of compound variables with complex outcomes.

We planned to use fuzzy logic to deal with uncertainty for diagnosis risk status of breast cancer.

This paper is organized as follows; general structure of fuzzy logic system is introduced in section II, design of the system is presented in section III and test system and discussion are presented in section IV.

\section{GENERAL StRUCTURE OF FUZZY LOGIC SySTEM}

Fuzzy logic system as seen in Fig. 1 consists of the following modules [17]:

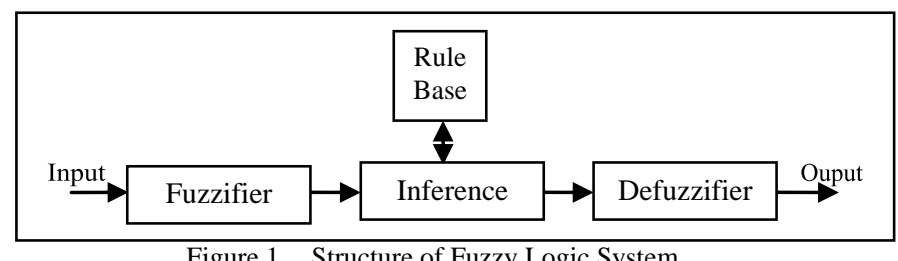

Figure 1. Structure of Fuzzy Logic System.

1. Fuzzification: - is the operation of transforming a crisp set to a fuzzy set. The operation translates crisp 
input or measured values into linguistic concepts by using suitable membership functions.

2. Inference Engine and Rule base:- Once the inputs are fuzzified, the corresponding inputs fuzzy sets are passed to the inference engine that processes current inputs using the rules retrieved from the rule base.

3. Defuzzifcation:- At the output of the fuzzy inference there will always be a fuzzy set that is obtained by the composition of the fuzzy sets output by each of the rules. In order to be used in the real world, the fuzzy output needs to be interfaced to the crisp domain by the defuzzifier by using suitable membership functions.

\section{DESIGN OF THE SYSTEM}

In this section, we show the fuzzy decision support system designing, membership functions, fuzzy rule base, fuzzification and defuzzification.

The most important application of fuzzy system (fuzzy logic) is in uncertain issues. When a problem has dynamic behavior, fuzzy logic is a suitable tool that deals with this problem. First step of fuzzy DSS designing is determination of input and output variables. There are six input variables and one output variable. After that, we must design membership functions (MF) of all variables. These membership functions determine the membership of objects to fuzzy sets.

At first, we will describe the input variables with their membership functions. In second step, we introduce the output variable with its membership functions. In next section, paper shows the rules of system and Fuzzification, Defuzzification process.

\section{A. Input Variables Are:}

1) HER2: Stands for "Human Epidermal growth factor Receptor 2" and is a protein giving higher aggressiveness in breast cancers [18]. This input variable has two fuzzy sets are "Negative" and "Positive". Membership functions of them are trapezoidal. Fuzzy sets Range of HER2 are identified in table I and membership functions for fuzzy sets are identified in Fig. 2

TABLE I. FUZZY SETS OF HER2 FACTOR

\begin{tabular}{|c|c|c|}
\hline Input Field & Range & Fuzzy set \\
\hline \multirow{3}{*}{ Her2 } & $<=1.5$ & Negative \\
\cline { 2 - 3 } & $1.5-3$ & May be Negative or Positive \\
\cline { 2 - 3 } & $>=3$ & Positive \\
\hline
\end{tabular}

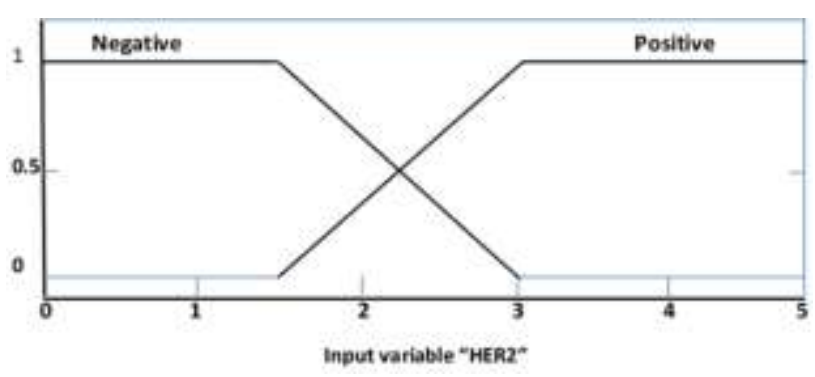

Figure 2. Membership Functions for HER2

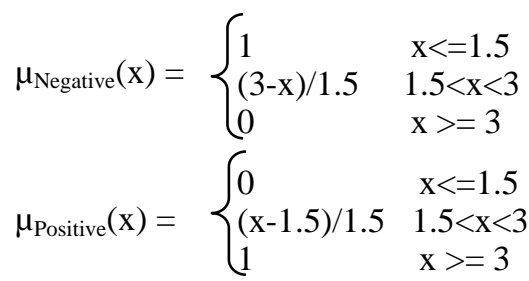

2) Hormone Receptor: Identifies sensitivity of breast to hormone [19]. This input variable has four fuzzy sets are Negative, Weak Positive, Moderate Positive and Strong Positive. Membership functions of Negative and Strong Positive fuzzy sets are trapezoidal, membership functions of Weak Positive and Moderate Positive are triangle. Table II identifies fuzzy sets range and Fig. 3 identifies membership functions of fuzzy sets.

TABLE II. FUZZY SETS OF HORMONE RECEPTORS

\begin{tabular}{|l|l|l|}
\hline Input Field & Range & Fuzzy set \\
\hline \multirow{4}{*}{ Hormone } & $<=10$ & Negative \\
\cline { 2 - 3 } & $10-15$ & May be Negative or Weak Positive \\
\cline { 2 - 3 } & $15-20$ & May be Weak Positive or Moderate Positive \\
\cline { 2 - 3 } & $20-35$ & Moderate Positive \\
\cline { 2 - 3 } & $35-40$ & May be Moderate Positive or Strong Positive \\
\cline { 2 - 3 } & $>=40$ & Strong Positive \\
\hline
\end{tabular}

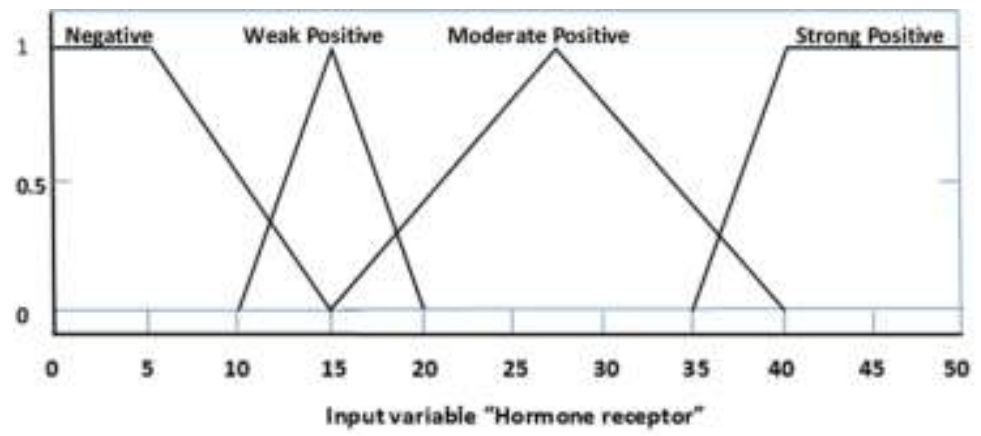

Figure 3. Membership Functions for Hormone Receptors

$\mu$ Negative $(\mathrm{x})= \begin{cases}1 & \mathrm{x}<=5 \\ (15-\mathrm{x}) / 10 & 5<\mathrm{x}<15 \\ 0 & \mathrm{x}>=15\end{cases}$
$\mu$ Weak Positive $(\mathrm{x})= \begin{cases}0 & \mathrm{x}<=10 \\ (\mathrm{x}-10) / 5 & 10<\mathrm{x}<15 \\ 1 & \mathrm{x}=15 \\ (20-\mathrm{x}) / 5 & 15<\mathrm{x}<20 \\ 0 & \mathrm{x}>=20\end{cases}$
$\mu$ Moderate Positive $(\mathrm{x})= \begin{cases}0 & \mathrm{x}<=15 \\ (\mathrm{x}-15) / 12.5 & 15<\mathrm{x}<27.5 \\ 1 & \mathrm{x}=27.5 \\ (40-\mathrm{x}) / 12.5 & 27.5<\mathrm{x}<40 \\ 0 & \mathrm{x}>=40\end{cases}$


$\mu$ Strong Positive $(\mathrm{x})= \begin{cases}0 & \mathrm{x}<=35 \\ \mathrm{x}-35) / 5 & 35<\mathrm{x}<40 \\ 1 & \mathrm{x}>=40\end{cases}$

3) Risk Age: This input variable has three fuzzy sets, are Very High, High And Low Risk age. Membership functions of these fuzzy sets are trapezoidal. Table III identifies fuzzy sets range and Fig. 4 identifies membership functions of them

TABLE III. FUZZY SETS OF RISK AGE

\begin{tabular}{|l|l|l|}
\hline Input Field & Range & Fuzzy set \\
\hline \multirow{4}{*}{ Age } & $<=20$ & Very High Risk \\
\cline { 2 - 3 } & $20-30$ & May be Very High Risk or High Risk \\
\cline { 2 - 3 } & $30-35$ & High Risk \\
\cline { 2 - 3 } & $35-45$ & May be High Risk or Low Risk \\
\cline { 2 - 3 } & $>=45$ & Low Risk \\
\hline
\end{tabular}

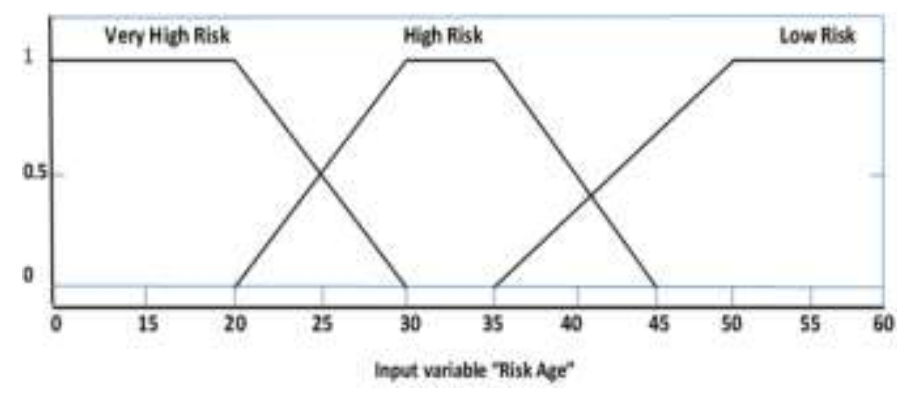

Figure 4. Membership Functions for Risk Age

$$
\begin{aligned}
& \mu \operatorname{VeryhighRisk}(x)=\left\{\begin{array}{lc}
1 & x<=20 \\
(30-x) / 10 & 20<x<30 \\
0 & x>=30
\end{array}\right. \\
& \mu \operatorname{HighRisk}(\mathrm{x})= \begin{cases}0 & \mathrm{x}<=20 \\
(\mathrm{x}-20) / 10 & 20<\mathrm{x}<30 \\
1 & 30=<\mathrm{x}<=35 \\
(45-\mathrm{x}) / 10 & 35<\mathrm{x}<45 \\
0 & \mathrm{x}>=45\end{cases} \\
& \mu \operatorname{LowRisk}(\mathrm{x})= \begin{cases}0 & \mathrm{x}<=35 \\
(\mathrm{x}-35) / 15 & 35<\mathrm{x}<50 \\
1 & \mathrm{x}>=50\end{cases}
\end{aligned}
$$

4) Tumor Grade: A description of a tumor based on how abnormal the cancer cells look under a microscope and how quickly the tumor is likely to grow and spread [20]. Grading systems are different for each type of cancer. This input variable has three fuzzy sets Grade1, Grade2 and Grade3. Membership functions of these fuzzy sets are trapezoidal. Table IV identifies fuzzy sets range and Fig. 5 identifies membership functions of them
TABLE IV. FUZZY SETS OF TUMOR GRADE

\begin{tabular}{|l|l|l|}
\hline Input Field & Range & Fuzzy set \\
\hline \multirow{4}{*}{ Grade } & $<=4$ & Grade1 \\
\cline { 2 - 3 } & $4-5.5$ & May be Grade1 or Grade2 \\
\cline { 2 - 3 } & $5.5-6$ & Grade2 \\
\cline { 2 - 3 } & $6-7.5$ & May be Grade2 or Grade3 \\
\cline { 2 - 3 } & $>=7.5$ & Grade3 \\
\hline
\end{tabular}

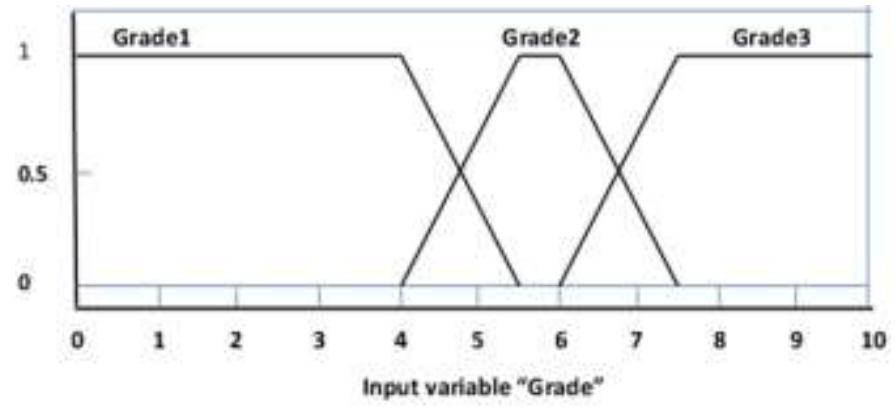

Figure 5. Membership Functions for Tumor Grade

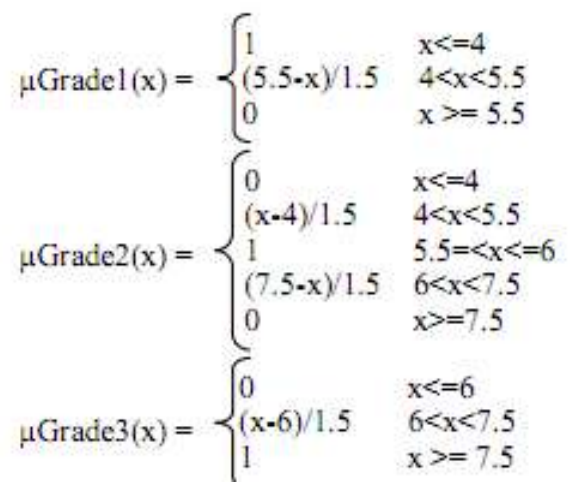

5) Lymph Node: A lymph node is part of the body's lymphatic system, in the lymphatic system, a network of lymph vessels carries clear fluid called lymph, lymph vessels lead to lymph nodes; with it cancer cells are likely to spread from the primary tumor [21]. This input variable is Zero or has two fuzzy sets are Intermediate Number(Intermediate No.) and High Number(High No.), membership functions for these fuzzy sets are trapezoidal.

Table $\mathrm{V}$ identifies fuzzy sets range of lymph node variable and Fig. 6 identifies membership functions of them.

TABLE V. FuZZY SETS OF LYMPH NODE

\begin{tabular}{|l|l|l|}
\hline Input Field & Range & Fuzzy set \\
\hline \multirow{3}{*}{ Lymph Node } & $1-2$ & Intermediate No. \\
\cline { 2 - 3 } & $2-10$ & May be Intermediate No. or High No. \\
\cline { 2 - 3 } & $>=10$ & High No. \\
\hline
\end{tabular}

$\mu$ IntermediateNo. $(x)= \begin{cases}1 & 1<=x<=2 \\ (10-x) / 8 & 2<x<10 \\ 0 & x>=10\end{cases}$

$\mu$ HighNo. $(x)= \begin{cases}0 & x<=2 \\ (x-2) / 10 & 2<x<12 \\ 1 & x>=12\end{cases}$ 


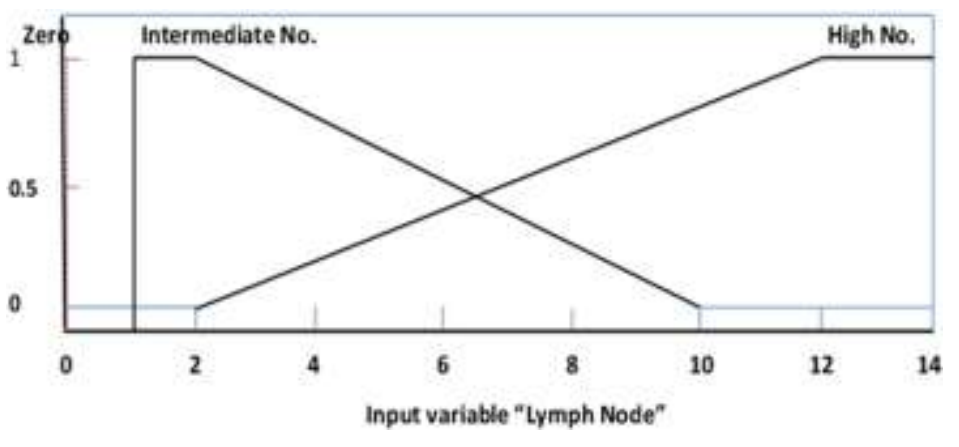

Figure 6. Membership Functions for Lymph Node

6) Tumor Size: This input variable has two fuzzy sets Small Size and Intermediate Size, membership functions for these fuzzy sets are trapezoidal, Table VI identifies fuzzy sets range of tumor size variable and Fig. 7 identifies membership functions of them.

TABLE VI. FUZZY SETS OF TUMOR SIZE

\begin{tabular}{|l|l|l|}
\hline Input Field & Range & Fuzzy set \\
\hline \multirow{4}{*}{ Tumor Size } & $<=2$ & Small Size \\
\cline { 2 - 3 } & $2-4$ & May be Small Size or Intermediate Size \\
\cline { 2 - 3 } & $>=4$ & Intermediate Size \\
\hline
\end{tabular}

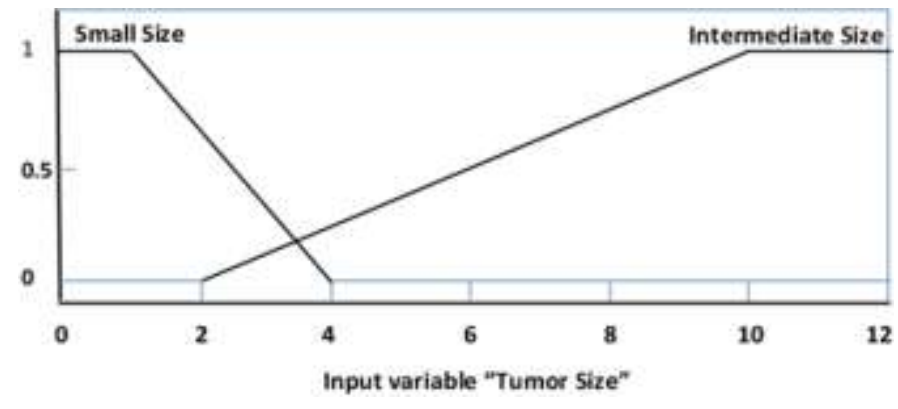

Figure 7. Membership Functions for Tumor Size

$$
\begin{aligned}
& \mu_{\text {SmallSize }}(x)= \begin{cases}1 & x<=1 \\
(4-x) / 3 & 1<x<4 \\
0 & x>=4\end{cases} \\
& \mu_{\text {IntermediateSize }}(\mathrm{x})= \begin{cases}0 & \mathrm{x}<=2 \\
(\mathrm{x}-2) / 8 & 2<\mathrm{x}<10 \\
1 & \mathrm{x}>=10\end{cases}
\end{aligned}
$$

\section{B. Output Variable Is:}

The "goal" of the system is to identify risk status of breast cancer recurrence or mortality in early diagnosed patients. The output variable is a value from 1 to 4 ; representing Low Risk status, Intermediate Risk status and High Risk status. By increasing the value, tumor risk increases. This output has three fuzzy sets Low Risk, Intermediate Risk And High Risk; table VII identifies these fuzzy sets and its range.

The membership functions of these fuzzy sets are triangle as shown in Fig. 8.

TABLE VII. FUZZY SETS OF OUtPUt VARIABLE RISK STATUS

\begin{tabular}{|c|c|l|}
\hline Output & Range & Fuzzy set \\
\hline \multirow{4}{*}{ Risk Status } & $0-2$ & Low Risk \\
\cline { 2 - 3 } & $1-3$ & Intermediate Risk \\
\cline { 2 - 3 } & $2-4$ & High Risk \\
\hline
\end{tabular}

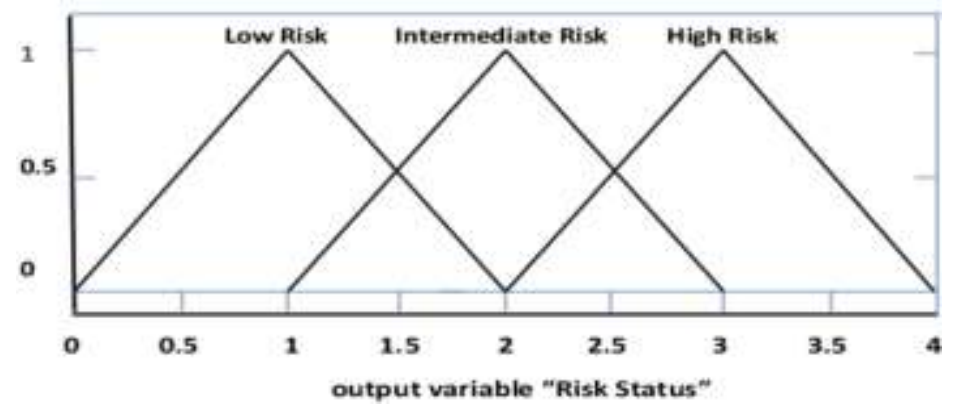

Figure 8. Membership Function For Output Variable Risk Status

\section{Fuzzy Rule Base}

The Rules Base is determined by the help of consultant doctors of the OCMU Center.

The rule base consists of 14 rules that determine the Risk status (High Risk, Intermediate Risk and Low Risk) by evaluation of the input variables mentioned above. Hormone receptor positivity level has no value in risk status characterization; however it plays an important role in further treatment decision. The rule base is shown in Table VIII

\section{Fuzzification and Defuzzification}

This system depends on Mamdani model for inference mechanism, in it and method is minimum (this system doesn't contains or operator), Implication method is minimum which involves defining the consequence as an output fuzzy set.

This can only be achieved after each rule has been evaluated and is allowed contribute its 'weight' in determining the output fuzzy set, Aggregation method between rules is maximum to combine output fuzzy set, so Fuzzification method here is max-min and Defuzzification method is centroid .

\section{TEST System AND DisCUSSION}

System has been tested by consultant oncologists and here is one of tested values as shown in Table IX and Fig. 9 
TABLE VIII. RULE BASE OF THE SYSTEM

\begin{tabular}{|c|l|l|l|l|l|l|l|}
\hline $\begin{array}{c}\text { Rule } \\
\text { NO }\end{array}$ & Her2 & \multicolumn{1}{|c|}{$\begin{array}{c}\text { Hormone } \\
\text { Receptors }\end{array}$} & Risk Age & Grade & $\begin{array}{c}\text { Tumor } \\
\text { Size }\end{array}$ & Lymph Node & Risk Status \\
\hline 1 & Negative & Weak Positive & Low & Grade1 & Small & Zero & Low Risk \\
\hline 2 & Negative & Weak Positive & High & Grade1 & Small & Zero & Low Risk \\
\hline 3 & Negative & Moderate Positive & Low & Grade1 & Small & Zero & Low Risk \\
\hline 4 & Negative & Moderate Positive & High & Grade1 & Small & Zero & Low Risk \\
\hline 5 & Negative & Strong Positive & Low & Grade1 & Small & Zero & Low Risk \\
\hline 6 & Negative & Strong Positive & High & Grade1 & Small & Zero & Low Risk \\
\hline 7 & Negative & Any & Any & Grade2 & Any & Zero & Intermediate Risk \\
\hline 8 & Negative & Any & Any & Grade3 & Any & Zero & Intermediate Risk \\
\hline 9 & Negative & Any & Any & Any & Intermediate & Zero & Intermediate Risk \\
\hline 10 & Negative & Any & Very High & Any & Any & Zero & Intermediate Risk \\
\hline 11 & Negative & Any & Any & Any & Any & Intermediate No. & Intermediate Risk \\
\hline 12 & Positive & Any & Any & Any & Any & Zero & Intermediate Risk \\
\hline 13 & Positive & Any & Any & Any & Any & Intermediate No. & High Risk \\
\hline 14 & Any & Any & Any & Any & Any & High No. & High Risk \\
\hline
\end{tabular}

TABLE IX. Tested VALUes

\begin{tabular}{|c|c|c|c|c|c|c|}
\hline Her2 & $\begin{array}{c}\text { Hormone } \\
\text { Receptors }\end{array}$ & Age & Grade & Tumor Size & $\begin{array}{c}\text { Lymph } \\
\text { Node }\end{array}$ & Risk Status \\
\hline 4 & 35 & 35 & 4 & 3 & 5 & 3 \\
\hline
\end{tabular}

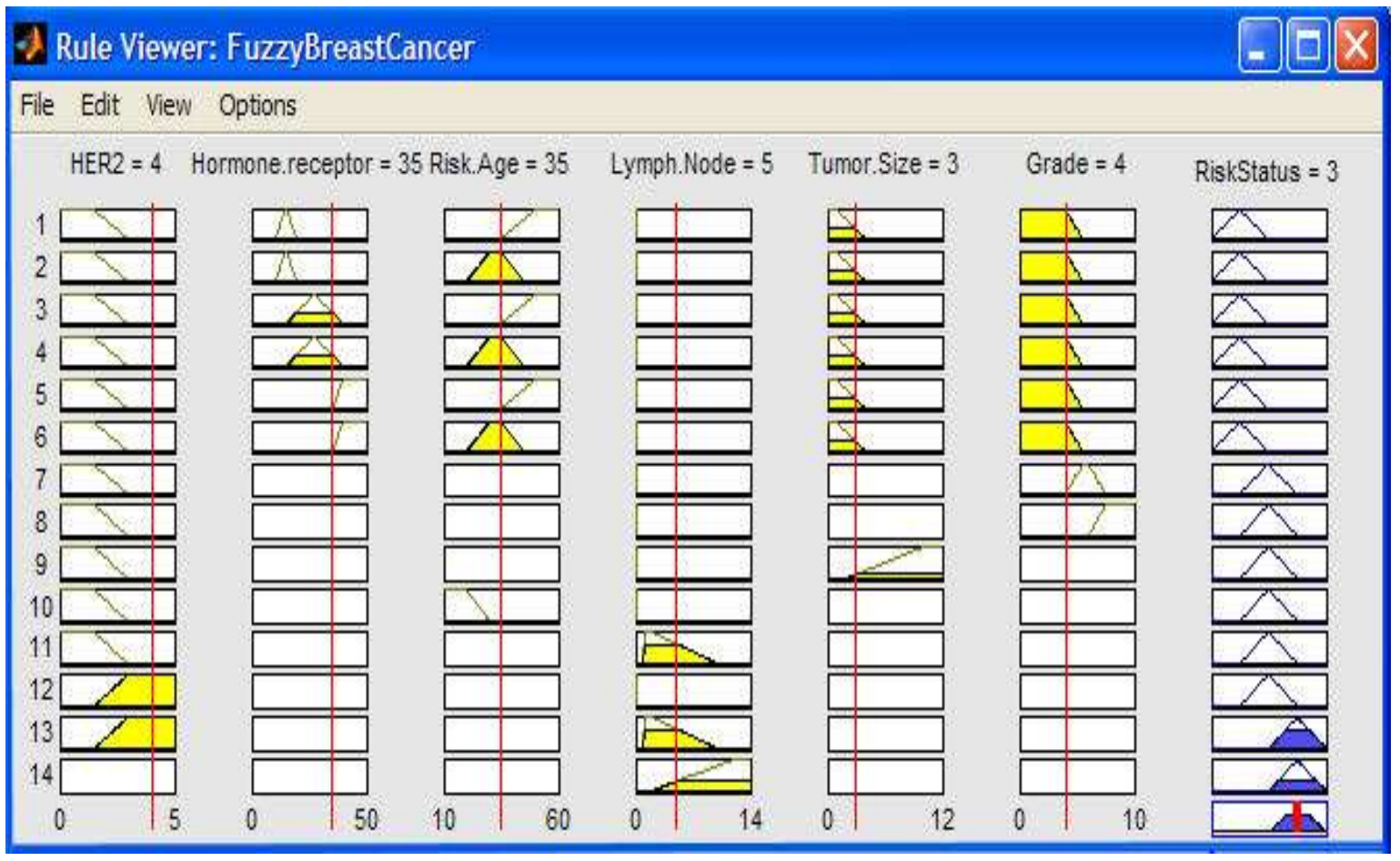

Figure 9. Result Of Tested Values 
And Fig. 10, 11, 12 and 13 shown surface viewer of some fields as follow:-

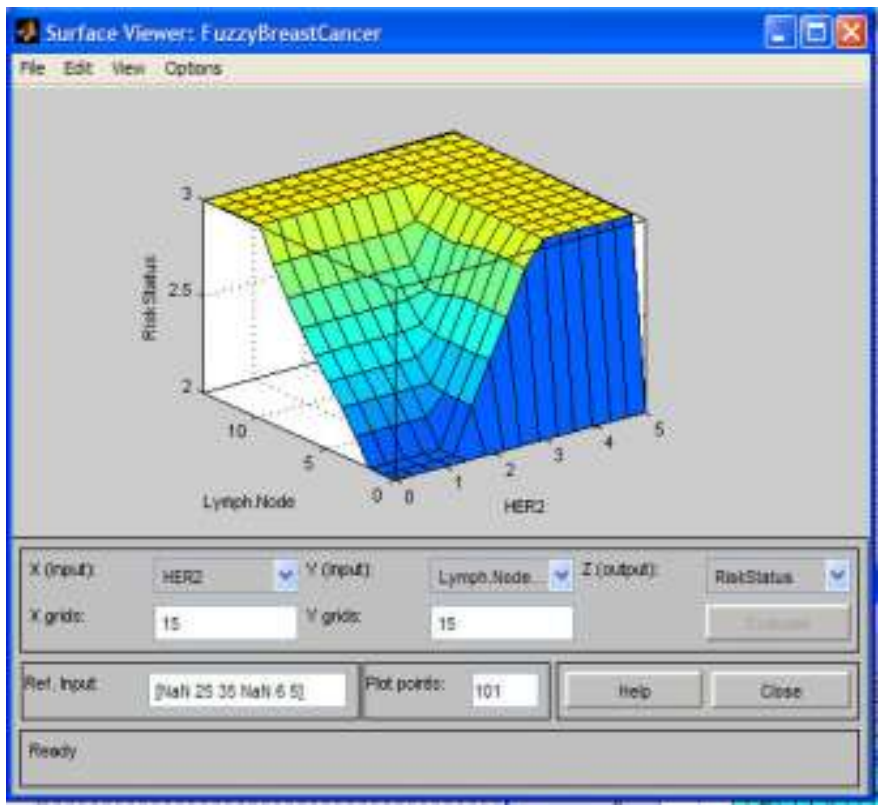

Figure 10. Surface Viewer of HER2 and Lymph Node

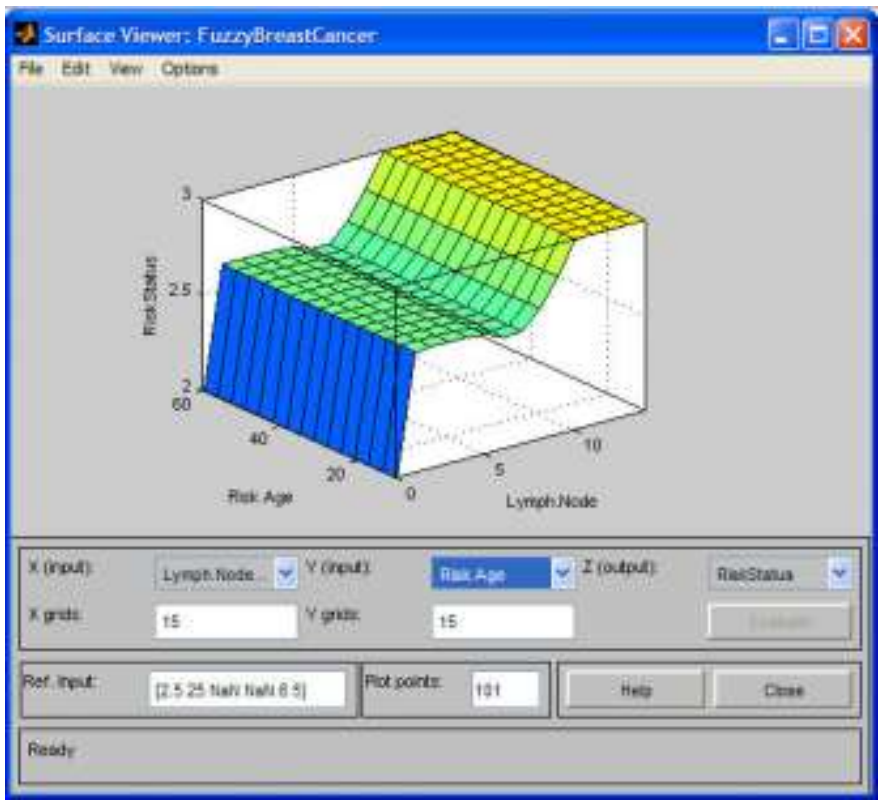

Figure 11. Surface Viewer of Hormone Receptor and Lymph Nod

\section{CONCLUSION AND FutURE WorK}

This paper describes design of fuzzy decision support system for identification of breast cancer risk status in situations of data diversity and imprecision, which can be used by specialized doctors for cancer treatment.

The system design with based on membership functions, input variables, output variables and rule base. This system has been tested and approved by consultant oncologists in OCMU (Oncology Center Mansoura University).

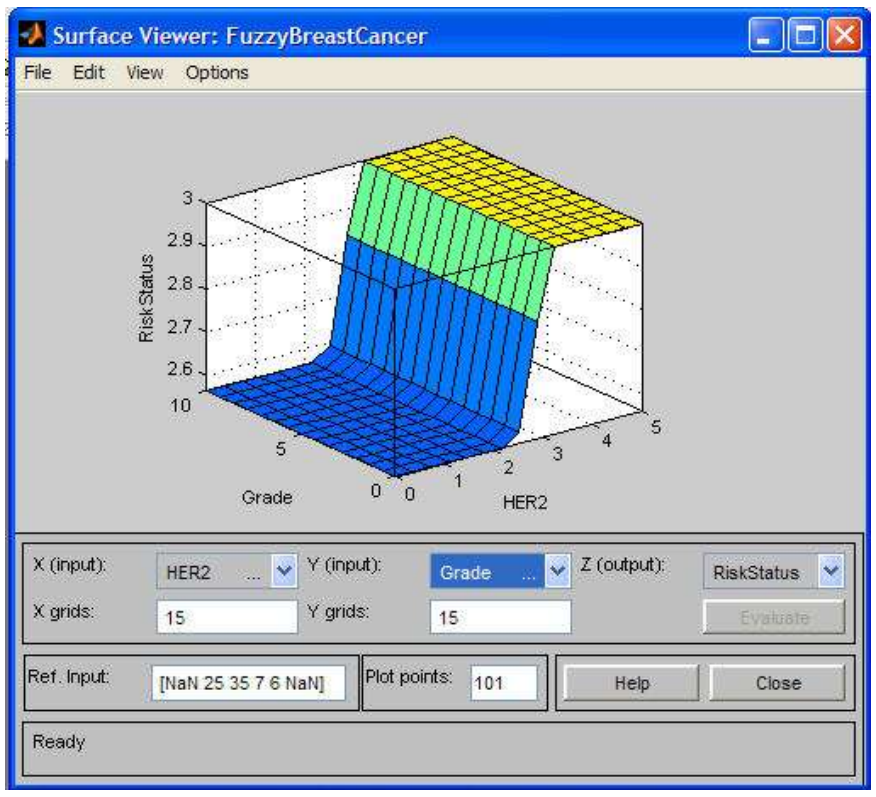

Figure 12. Surface Viewer of HER 2 and Tumor Grade

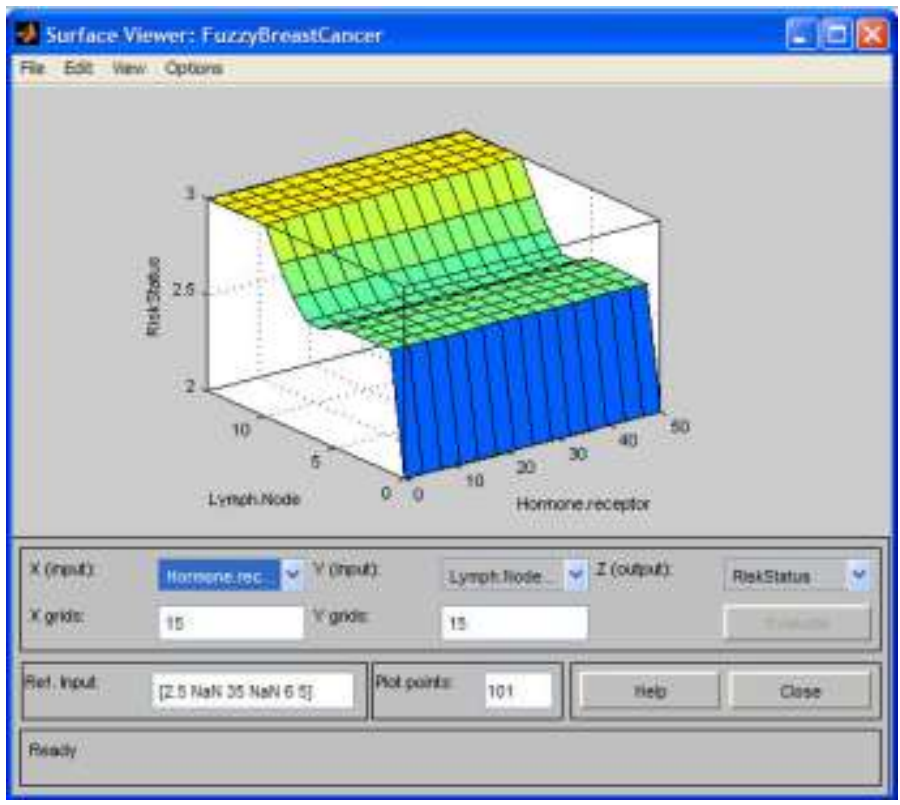

Figure 13. Surface Viewer of Hormone Receptor and Lymph Node

In future this system can be applied for other types of cancers. In addition it can integrate the more complex evolving molecular data in cancer diagnosis.

\section{ACKNOWLEDGMENTS}

We acknowledge Dr. Mohamed Awad Ebrahim Lecturer in Faculty of Medicine, Oncology Center Mansoura University for his efforts in this research. 


\section{REFERENCES}

[1] "Clinical decision support system" available on http://www.openclinical.org/dss.html.

[2] "Using decision support to help explain clinical manifestations of disease", available on http://lcs.mgh.harvard.edu/projects/dxplain.html.

[3] A. Aiken, D. Sleeman "AKT-R4: "Supporting the Exploration of a Knowledge Web" , Scotland, 2005.

[4] C. Goodman, "A Pilot Reference to organizations, assessments and information resources Care Technology" , National Academies Press, 1988.

[5] M. L. Graber and A. Mathew, "Performance of a Web-Based Clinical Diagnosis Support System for Internists" , Society of General Internal Medicine, USA, 2007.

[6] "Free Patient online search "available on :http://www.freepatentsonline.com/.

[7] J. H. Knab, M.S. Wallace, R. L. Wagner, J. Tsoukatos, and M. B. Weinger, "The Use of a Computer-Based Decision Support System Facilitates Primary Care Physicians Management of Chronic Pain" , ANESTH ANALG journal, vol. 93, pp 712-720, September 2001 .

[8] P. Hammond and M. Sergot "Computer Support For Protocol-Based Treatment Of Cancer", Journal of Logic Programming, vol. 26, pp 93$111,1996$.

[9] J. P. Bury, C. Hurt, C. Bateman, S. Atwal, K. Riddy, J. Fox and V. Saha, "LISA: A Clinical Information and Decision Support System for Childhood Acute Lymphoblastic Leukaemia" Proceedings of the AMIA Annual Symposium, UK London, pp. 988, 2002.

[10] A. Torres and J. J. Nieto, " Fuzzy Logic in Medicine and Bioinformatics", Hindawi Publishing Corporation, Journal of Biomedicine and Biotechnology, Article ID 91908, pp 1-7, 2006.

[11] Ahmad, Y., \& Husain, S. (2010). Applying Intuitionistic Fuzzy Approach to Reduce Search Domain in an Accidental Case. International Journal of Advanced Computer Science and Applications -
IJACSA, 1(4).

[12] Khan, A. R. (2011). Knowledge-Based Systems Modeling for Software Process Model Selection. International Journal of Advanced Computer Science and Applications - IJACSA, 2(2), 20-25.

[13] N. H. Phuong, "Fuzzy set theory and medical expert systems: Survey and model" , Theory and Practice of Informatics book Springer Berlin / Heidelberg publisher, vol. 1012, pp 431-436,1995.

[14] N. H. Phuong and V. Kreinovich, "Fuzzy logic and its applications in medicine ", International Journal of Medical Informatics, vol. 62, no. 23, pp. 165-173, 2001.

[15] N. Kawahata and M. I. MacEntee, "A Measure of Agreement Between Clinicians and a Computer-Based Decision Support System for Planning Dental Treatment", Journal of Dental Education, vol. 66, Issue. 9, pp. 1031-1037, 2002.

[16] K. P. Adlassnig, "Fuzzy Systems in Medicine", vol. 21, Issue 1, pp 139146, 2001.

[17] A. R. Filho, "MDSS, Medical Diagnosis Support System",2008

[18] S. Omar, H. Khaled, R. Gaafar, A.R. Zekry, S. Eissa and O. El-Khatib, "Breast cancer in Egypt: a review of disease presentation and detection strategies", Eastern Mediterranean Health Journal, vol. 9, no. 3, pp. 448463, 2003.

[19] J.C. Bezdek, "Editorial: Fuzzy Models? What Are They, and Why?" IEEE Transactions on Fuzzy Systems, vol. 1, pp 1-5, February 1993.

[20] "what is her2" available on http://www.herceptin.com/her2-breastcancer/testing-education/what-is.jsp

[21] "Are Hormone Receptors Present?" Available on http://www.breastcancer.org/symptoms/diagnosis/horm_receptors.jsp

[22] "Dictionary of Cancer Terms" available on http://www.cancer.gov/dictionary/?CdrID $=45702$

[23] "National Cancer Institute Sentinel Lymph Node Biopsy" available on http://www.cancer.gov/cancertopics/factsheet/therapy/sentinel-nodebiopsy 